\title{
Role of hydroxyl groups in the preferential oxidation of CO over copper oxide-cerium oxide catalysts
}

Arantxa Davó-Quiñonero, Miriam Navlani-García, Dolores Lozano-Castello, Agustín Bueno-López, and James A. Anderson

ACS Catal., Just Accepted Manuscript • DOI: 10.1021/acscatal.5b02741 • Publication Date (Web): 01 Feb 2016

Downloaded from http://pubs.acs.org on February 8, 2016

\section{Just Accepted}

"Just Accepted" manuscripts have been peer-reviewed and accepted for publication. They are posted online prior to technical editing, formatting for publication and author proofing. The American Chemical Society provides "Just Accepted" as a free service to the research community to expedite the dissemination of scientific material as soon as possible after acceptance. "Just Accepted" manuscripts appear in full in PDF format accompanied by an HTML abstract. "Just Accepted" manuscripts have been fully peer reviewed, but should not be considered the official version of record. They are accessible to all readers and citable by the Digital Object Identifier (DOI®). "Just Accepted" is an optional service offered to authors. Therefore, the "Just Accepted" Web site may not include all articles that will be published in the journal. After a manuscript is technically edited and formatted, it will be removed from the "Just Accepted" Web site and published as an ASAP article. Note that technical editing may introduce minor changes to the manuscript text and/or graphics which could affect content, and all legal disclaimers and ethical guidelines that apply to the journal pertain. ACS cannot be held responsible for errors or consequences arising from the use of information contained in these "Just Accepted" manuscripts. 


\title{
Role of hydroxyl groups in the preferential oxidation
}

\section{of CO over copper oxide-cerium oxide catalysts}

\author{
Arantxa Davó-Quiñonero ${ }^{1}$, Miriam Navlani-García ${ }^{1}$, Dolores Lozano-Castelló ${ }^{1,2}$, Agustín $^{2}$ \\ Bueno-López ${ }^{1,2, *}$, James A. Anderson ${ }^{2}$ \\ ${ }^{1}$ MCMA group. Inorganic Chemistry Department; University of Alicante. \\ ${ }^{2}$ Surface Chemistry and Catalysis Group, School of Engineering, University of Aberdeen.
}

KEYWORDS. PROX; copper; ceria, $\mathrm{CO}$ oxidation; $\mathrm{H}_{2}$ purification. 
ABSTRACT

Model $\mathrm{CuO} / \mathrm{Ce}_{0.8} \mathrm{X}_{0.2} \mathrm{O}_{\delta}$ catalysts (with $\mathrm{X}=\mathrm{Ce}, \mathrm{Zr}$, La, Pr or $\mathrm{Nd}$ ) have been prepared in order to obtain $\mathrm{CuO} /$ ceria materials with different chemical features, and have been characterized by XRD, Raman spectroscopy, $\mathrm{N}_{2}$ adsorption and $\mathrm{H}_{2}$-TPR. CO-PROX experiments have been performed in a fixed-bed reactor and in an operando DRIFTS cell coupled to a mass spectrometer. The $\mathrm{CO}$ oxidation rate over $\mathrm{CuO} / \mathrm{Ceria}$ catalysts correlates with the formation of the $\mathrm{Cu}^{+}-\mathrm{CO}$ carbonyl above a critical temperature $\left(90^{\circ} \mathrm{C}\right.$ for the experimental conditions in this study) because copper-carbonyl formation is the rate limiting step. Above this temperature CO oxidation capacity depends on the redox properties of the catalyst. However, decomposition of adsorbed intermediates is the slowest step below this threshold temperature. The hydroxyl groups on the catalyst surface play a key role in determining the nature of the carbon-based intermediates formed upon $\mathrm{CO}$ chemisorption and oxidation. Hydroxyls favor the formation of bicarbonates with respect to carbonates, and catalyst forming more bicarbonates produce faster $\mathrm{CO}$ oxidation rates than those which favor carbonates. 


\section{1.- Introduction}

$\mathrm{CO}$ oxidation by molecular oxygen is probably one of the most studied catalyzed reactions, and the selective oxidation of $\mathrm{CO}$ in $\mathrm{H}_{2}$-rich gas mixtures (CO-PROX) has become of special relevance in recent years in order to provide sufficiently pure $\mathrm{H}_{2}$ for proton exchange membrane fuel cells (PEMFC). ${ }^{1,2} \mathrm{H}_{2}$ is obtained by catalytic reforming of hydrocarbons followed by the water gas shift reaction (WGS), ${ }^{3}$ and this process yields a $\mathrm{H}_{2}$-rich gas stream with up to $1 \%$ of CO. This high concentration is not acceptable because CO poisons the Pt electrocatalysts, and CO concentration must be lowered below ca. $100 \mathrm{ppm}^{4}$ The CO-PROX reaction is one of the most suitable methods for the purification of such $\mathrm{H}_{2}$-rich gas streams, and copper oxide-cerium oxide catalysts are promising materials ${ }^{5-8}$ for CO-PROX that could replace expensive $\mathrm{Pt}$ or $\mathrm{Au}$ catalysts. $^{9-13}$

The CO-PROX reaction is a competitive process where $\mathrm{CO}$ and $\mathrm{H}_{2}$ compete with each other for molecular oxygen ${ }^{14}$. The catalyst must be selective towards the $\mathrm{CO}-\mathrm{O}_{2}$ reaction with regard to the undesired oxidation of $\mathrm{H}_{2}$, which decreases the net $\mathrm{H}_{2}$ yield of the complete catalytic reforming + WGS + CO-PROX series of reactions. A correlation was established between the $\mathrm{CO}$ oxidation rate and the level of interfacial reduction of $\mathrm{Cu}^{2+}$ to $\mathrm{Cu}^{+}$, and such interfacial reduction can be correlated to the formation of $\mathrm{Cu}^{+}-\mathrm{CO}$ carbonyls. ${ }^{15,16}$ On the other hand, the oxidation of $\mathrm{H}_{2}$ occurs once copper is significantly reduced, and the active species for the $\mathrm{H}_{2}-\mathrm{O}_{2}$ reaction are partially reduced copper oxide nanoparticles ${ }^{15}$ where dissociative chemisorption of $\mathrm{H}_{2}$ takes place. ${ }^{17}$ The selectivity of copper oxide-cerium oxide catalysts can be related to the preferential adsorption of $\mathrm{CO}$ on $\mathrm{Cu}^{+}$and hindered $\mathrm{H}_{2}$ dissociation on oxidized sites. ${ }^{17}$ 
The evolution of the carbon-containing species on the catalysts surface during the course of the reaction is complex and is not completely understood, but it has been reported that surface hydroxyls on the catalyst have a positive effect on $\mathrm{CO}$ oxidation for noble metal catalyst. ${ }^{18}$ This aspect has been analyzed in detail in this study for $\mathrm{CuO} / \mathrm{Ceria}$, and model $\mathrm{CuO} / \mathrm{Ce}_{0.8} \mathrm{X}_{0.2} \mathrm{O}_{\delta}$ catalysts (with $\mathrm{X}=\mathrm{Ce}, \mathrm{Zr}$, La, Pr or $\mathrm{Nd}$ ) have been prepared in order to obtain $\mathrm{CuO} / \mathrm{Ceria}$ materials with different chemical features. The objectives were to understand the role of the carbon containing intermediates in the $\mathrm{CO}$ oxidation reaction, and to determine whether the hydroxyl groups on the catalyst influence the formation of bicarbonates in preference to carbonates, and to provide evidence to support a hypothesis that catalysts which preferentially form bicarbonates are able to oxidize $\mathrm{CO}$ faster than those forming carbonates-type species.

\section{2.- Experimental}

2.1 Catalysts preparation.

Five metal oxides with composition $\mathrm{Ce}_{0.8} \mathrm{X}_{0.2} \mathrm{O}_{\delta}(\mathrm{X}=\mathrm{Ce}, \mathrm{Zr}, \mathrm{La}$, Pr or $\mathrm{Nd})$ were prepared using the following metal precursors: $\mathrm{Ce}\left(\mathrm{NO}_{3}\right)_{3} \cdot 6 \mathrm{H}_{2} \mathrm{O}$ (Alfa-Aesar, $99.5 \%$ ), $\mathrm{ZrO}\left(\mathrm{NO}_{3}\right)_{2} \cdot \mathrm{xH}_{2} \mathrm{O}$ (Fluka, $27 \% \mathrm{Zr}), \mathrm{La}\left(\mathrm{NO}_{3}\right)_{3} \cdot 6 \mathrm{H}_{2} \mathrm{O}(\geq 99.0 \%), \operatorname{Pr}\left(\mathrm{NO}_{3}\right)_{3} \cdot 6 \mathrm{H}_{2} \mathrm{O}(99.9 \%)$ and $\mathrm{Nd}\left(\mathrm{NO}_{3}\right)_{3} \cdot 6 \mathrm{H}_{2} \mathrm{O}(\geq$ $99.9 \%)$.

The amounts of each precursor used were those required to obtain $5 \mathrm{~g}$ of metal oxide, and aqueous solutions of these amounts were prepared with $10 \mathrm{ml}$ of solvent. The dissolutions were introduced in a muffle furnace previously heated at $200^{\circ} \mathrm{C}$, and after 1 hour, the temperature was increased at $10^{\circ} \mathrm{C} / \mathrm{min}$ until $500^{\circ} \mathrm{C}$, holding the samples at this temperature for 2 hours. 
$\mathrm{CuO} / \mathrm{Ce}_{0.8} \mathrm{X}_{0.2} \mathrm{O}_{\delta}$ catalysts were prepared afterwards with a 5 wt. \% target $\mathrm{Cu}$ loading. The required amount of $\mathrm{Cu}\left(\mathrm{NO}_{3}\right)_{2} \cdot 5 \cdot(1 / 2) \mathrm{H}_{2} \mathrm{O}$ (Sigma Aldrich, $98 \%$ ) was dissolved in $2 \mathrm{ml}$ of water and $2.5 \mathrm{~g}$ of $\mathrm{Ce}_{0.8} \mathrm{X}_{0.2} \mathrm{O}_{\delta}$ was impregnated with this solution. The impregnated supports were heat treated following the same protocol used for the supports preparation, that is, they were introduced in a muffle furnace previously heated at $200^{\circ} \mathrm{C}$, and after $1 \mathrm{~h}$, the temperature was increased at $10^{\circ} \mathrm{C} / \mathrm{min}$ until $500^{\circ} \mathrm{C}$, holding this temperature for $2 \mathrm{~h}$.

\section{2. Catalysts characterization.}

X-ray diffractograms were obtained in a Bruker D8 advance diffractometer, using CuK $\alpha$ radiation $(\lambda=0.15418 \mathrm{~nm})$ between 10 and $90^{\circ}(2 \theta)$, with a step of $0.02^{\circ}$ and a time of $3 \mathrm{~s}$ per step. The average crystallite size of the mixed oxide supports was determined using the Williamson-Hall's equation. ${ }^{19}$

$\mathrm{N}_{2}$ adsorption isotherms were performed at $-196^{\circ} \mathrm{C}$ in an automatic volumetric system (Autosorb-6, Quantachrome) after the catalysts were degassed at $150^{\circ} \mathrm{C}$ for $4 \mathrm{~h}$. The specific surface areas, pore volumes and pore sizes were determined with the BET, DR and BJH methods, respectively.

Raman spectra were recorded in a Bruker RFS 100/S Fourier Transform Raman Spectrometer with a variable power Nd-YAG laser source $(1064 \mathrm{~nm})$. The spectra shown in this document were normalized by dividing the intensity of each spectrum by the intensity of its $\mathrm{F}_{2 \mathrm{~g}}$ band maximum.

The catalysts were characterized by Temperature Programmed Reduction with $\mathrm{H}_{2}\left(\mathrm{H}_{2}-\mathrm{TPR}\right)$ in a ThermoQuest device (LE instruments), consisting of a tubular quartz reactor coupled to a 
thermal conductivity detector (TCD). The experiments were conducted with $50 \mathrm{mg}$ of catalyst. The temperature was raised at $10^{\circ} \mathrm{C} \cdot \mathrm{min}^{-1}$ from room temperature to $900^{\circ} \mathrm{C}$ and a $30 \mathrm{~mL} \cdot \mathrm{min}^{-1}$ flow of $5 \mathrm{vol} \% \mathrm{H}_{2}$ in $\mathrm{N}_{2}$ was used. A CuO reference sample was used to quantify the amount of $\mathrm{H}_{2}$ consumed in the experiments, and two parameters were calculated:

$$
\mathrm{H}_{2 \text { consumed }} \mathrm{mol} / \mathrm{CuO} \mathrm{mol}=\frac{\mathrm{H}_{2} \text { mol consumed }}{\mathrm{CuO} \mathrm{mol}}
$$

where " $\mathrm{H}_{2}$ mol consumed" are the total moles of $\mathrm{H}_{2}$ consumed in a certain $\mathrm{H}_{2}$-TPR experiment and "CuO mol" are the $\mathrm{CuO}$ mol on the parcel of catalyst used in that $\mathrm{H}_{2}-\mathrm{TPR}$ experiment. The $\mathrm{H}_{2}$ mol consumed by the catalysts were calculated integrating the area under the TCD signal profiles, and converting these areas into $\mathrm{H}_{2}$ mole considering the area of the reduction peak obtained with the reference $\mathrm{CuO}$ sample and assuming total reduction to $\mathrm{Cu}^{0}$.

$$
\mathrm{Ce}^{4+} \text { reduced }(\%)=100 \cdot \frac{2 \cdot\left(\mathrm{H}_{2} \text { mol consumed }-\mathrm{H}_{2} \text { mol for } \mathrm{CuO} \text { reduction }\right)}{\text { Ce moles }}
$$

where " $\mathrm{H}_{2}$ mol for $\mathrm{CuO}$ reduction" are the moles of $\mathrm{H}_{2}$ required for all $\mathrm{CuO}$ in the sample of catalyst to be reduced to $\mathrm{Cu}^{0}$ and "Ce moles" are the total moles of $\mathrm{Ce}$ in the sample of catalyst.

\subsection{Catalytic tests in a fixed-bed reactor.}

Catalytic tests were carried out in a U-shape quartz reactor (16 $\mathrm{mm}$ inner diameter) with 150 $\mathrm{mg}$ of catalyst and $100 \mathrm{~mL} / \mathrm{min}\left(30000 \mathrm{~h}^{-1}\right)$ of a gas mixture with $2 \% \mathrm{CO}, 2 \% \mathrm{O}_{2}$ and $30 \% \mathrm{H}_{2}$ balanced with He. The gas stream was fed to the reactor by means of mass flow controllers (Bronkhorst). The gas composition was monitored after the reaction with a gas chromatograph 
Agilent Technologies $6890 \mathrm{~N}$, equipped with a CRT column operating at $80{ }^{\circ} \mathrm{C}$ and a TCD detector.

Variable temperature and isothermal experiments were carried out. In variable temperature experiments, the temperature was raised at $2^{\circ} \mathrm{C} / \mathrm{min}$ until reaching $200^{\circ} \mathrm{C}$. Consecutive ramp experiments were performed with selected catalysts using the same aliquot of sample. After the first ramp, the catalyst was reoxidized at $200^{\circ} \mathrm{C}$ in $10 \% \mathrm{O}_{2} / \mathrm{He}$ flow for $1 \mathrm{~h}$ and then cooled to room temperature in inert gas. Then, the reaction gas mixture was fed to the reactor and the temperature was raised at $2^{\circ} \mathrm{C} / \mathrm{min}$ until $200^{\circ} \mathrm{C}$, repeating this protocol four times. After the fourth run, the catalysts were reoxidized and cooled as described, and a fifth heating step was carried out with the reaction gas mixture, but in this case the temperature was stabilized at $120^{\circ} \mathrm{C}$ and the selected catalysts were held under these reaction conditions for $12 \mathrm{~h}$ in order to evaluate the long-term stability.

CO conversion and selectivity were calculated as follows:

$$
\text { CO conversion }(\%)=\frac{\mathrm{P}_{\mathrm{CO}}^{\text {in }}-\mathrm{P}_{\mathrm{CO}}^{\text {out }}}{\mathrm{P}_{\mathrm{CO}}^{\text {in }}} \cdot 100 \quad \text { CO selectivity }(\%)=\frac{\mathrm{P}_{\mathrm{CO}}^{\text {in }}-\mathrm{P}_{\mathrm{CO}}^{\text {out }}}{\mathrm{P}_{\mathrm{O}_{2}}^{\text {in }}-\mathrm{P}_{\mathrm{O}_{2}}^{\text {out }}} \cdot 50
$$

where $\mathrm{P}_{\mathrm{CO}}^{\text {in }}$ and $\mathrm{P}_{\mathrm{CO}}^{\text {out }}$ are the inlet and outlet $\mathrm{CO}$ partial pressures, respectively, and $\mathrm{P}_{\mathrm{O}_{2}}^{\text {in }}$ and $\mathrm{P}_{\mathrm{O}_{2}}^{\text {out }}$ are the $\mathrm{O}_{2}$ partial pressures.

\subsection{Operando DRIFTS-MS experiments.}

The reaction mechanism was studied in a Shimadzu (IR Tracer-100) Fourier Transform Infrared Spectrometer with a Harrick reaction cell coupled to a EcoSys-P mass spectrometer. The reaction cell was designed to allow the reaction gas mixture $\left(2 \% \mathrm{CO}, 2 \% \mathrm{O}_{2}\right.$ and $58 \% \mathrm{H}_{2}$ 
balanced with $\mathrm{He} ; 50 \mathrm{ml} / \mathrm{min})$ to pass through the catalyst bed (100 $\mathrm{mg}$ without any diluent) with the gas exit at the bottom.

The catalysts were first pretreated at $400^{\circ} \mathrm{C}$ for $15 \mathrm{~min}$ in a flow of air, and the reaction cell was cooled afterwards to room temperature while maintaining the air flow. A background spectrum was recorded for each catalyst at room temperature after this cleaning step, and then, air was replaced by the reaction gas mixture and the temperature was raised at $5^{\circ} \mathrm{C} / \mathrm{min}$ while infrared spectra were recorded at $10^{\circ} \mathrm{C}$ intervals. Each spectrum was obtained as an average of 75 scans, in the range 4000 to $1000 \mathrm{~cm}^{-1}$ with a resolution of $2 \mathrm{~cm}^{-1}$. The background spectrum of each catalyst was subtracted from those obtained under reaction conditions, and therefore, the features observed can be attributed to species formed or depleted during the reaction rather than to the catalysts structure.

\section{3.- Results and discussion}

3.1. Catalysts characterization by $\mathrm{N}_{2}$ adsorption, XRD and Raman spectroscopy.

The crystalline structure and porosity of the catalysts was characterized by XRD, $\mathrm{N}_{2}$ adsorption, and Raman spectroscopy. The X-ray diffractograms are compiled in Figure 1 and the crystallite sizes and cell parameters calculated for the ceria-based supports are compiled in Table 1. 


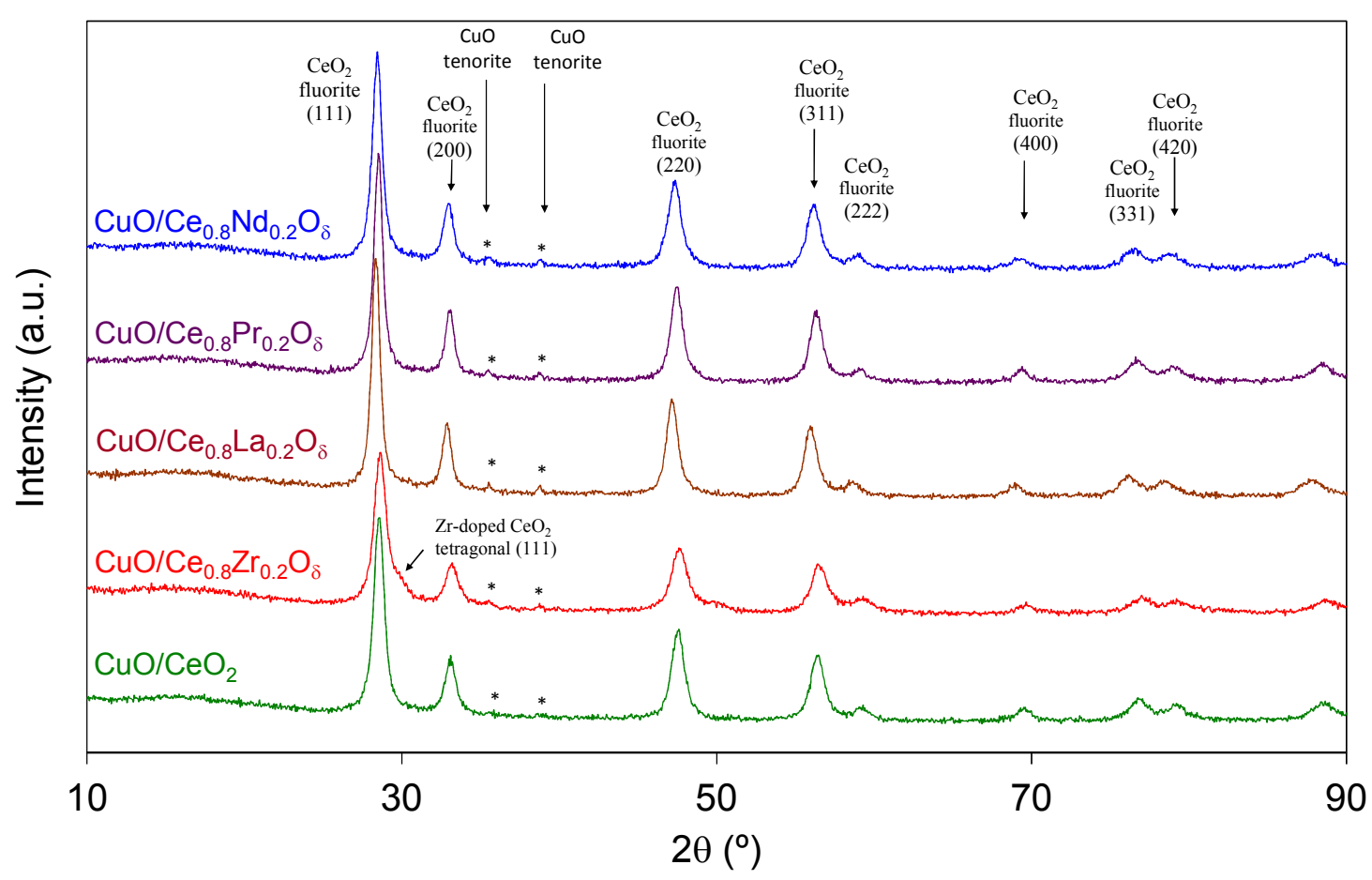

Figure 1. X-Ray diffractograms of the catalysts.

All diffractograms show the typical reflexions of the fluorite structure of ceria, and also tiny peaks of $\mathrm{CuO}$ at 35.7 and $39.0^{\circ}$ seem to be present in most catalyst. Evidence of other crystalline phases are only identified for the $\mathrm{CuO} / \mathrm{Ce}_{0.8} \mathrm{Zr}_{0.2} \mathrm{O}_{\delta}$ catalyst, which shows a shoulder at lower angles of the (111) fluorite peak at $29.0^{\circ}$ that is consistent with the presence of a $\mathrm{Zr}$-rich tetragonal phase (peak 111). Evidence of segregated phases of La, Pr or $\mathrm{Nd}$ was not observed in the diffractograms. 
Table 1. Results of the catalysts characterization by $\mathrm{N}_{2}$ adsorption, XRD and Raman spectroscopy.

The cell parameter calculated for the ceria bare support $(0.5407 \mathrm{~nm})$ is consistent with values typically obtained for this material, ${ }^{20}$ and doping with some cations affect this value. The cell parameter does not change significantly upon ceria doping with $\operatorname{Pr}$, which is not surprising because the sizes of the Ce cations $\left(0.097 \mathrm{~nm}\right.$ for $\mathrm{Ce}^{4+}$ and $0.114 \mathrm{~nm}$ for $\left.\mathrm{Ce}^{3+}\right)$ are almost equal

\begin{tabular}{|l|c|c|c|c|c|c|}
\hline Catalyst & $\begin{array}{c}\mathrm{BET} \\
\left(\mathrm{m}^{2} / \mathrm{g}\right)\end{array}$ & $\begin{array}{c}\text { Pore } \\
\text { volume DR } \\
\left(\mathrm{cm}^{3} / \mathrm{g}\right)\end{array}$ & $\begin{array}{c}\text { Pore size } \\
\mathrm{BJH} \\
(\mathrm{nm})\end{array}$ & $\begin{array}{c}\text { Crystallite } \\
\text { size } \\
(\mathrm{nm})\end{array}$ & $\begin{array}{c}\text { Cell } \\
\text { parameter } \\
(\mathrm{nm})\end{array}$ & $\begin{array}{c}\mathrm{F}_{2 \mathrm{~g}} \text { band } \\
\text { Raman shift } \\
\left(\mathrm{cm}^{-1}\right)\end{array}$ \\
\hline $\mathrm{CuO} / \mathrm{CeO}_{2}$ & 58 & 0.021 & 12 & 13 & 0.5407 & 441 \\
\hline $\mathrm{CuO} / \mathrm{Ce}_{0.8} \mathrm{Zr}_{0.2} \mathrm{O}_{\delta}$ & 60 & 0.020 & 12 & 13 & 0.5392 & 457 \\
\hline $\mathrm{CuO} / \mathrm{Ce}_{0.8} \mathrm{La}_{0.2} \mathrm{O}_{\delta}$ & 40 & 0.015 & 17 & 26 & 0.5448 & 446 \\
\hline $\mathrm{CuO} / \mathrm{Ce}_{0.8} \mathrm{Pr}_{0.2} \mathrm{O}_{\delta}$ & 35 & 0.013 & 12 & 27 & 0.5411 & 450 \\
\hline $\mathrm{CuO} / \mathrm{Ce}_{0.8} \mathrm{Nd}_{0.2} \mathrm{O}_{\delta}$ & 45 & 0.016 & 12 & 16 & 0.5429 & 453 \\
\hline
\end{tabular}
to those of $\operatorname{Pr}$ cations $\left(0.096 \mathrm{~nm}\right.$ for $\operatorname{Pr}^{4+}$ and $0.113 \mathrm{~nm}$ for $\left.\operatorname{Pr}^{3+}\right){ }^{21}$ On the contrary, $\mathrm{Zr}$ doping decreases the cell parameter of ceria while doping with La or $\mathrm{Nd}$ increases the cell parameter. The cell parameter contraction upon $\mathrm{Zr}$ doping is expected considering the smaller size of $\mathrm{Zr}^{4+}$ (0.084 nm) with regard to $\mathrm{Ce}^{4+}$, and the cell expansion upon $\mathrm{La}$ or $\mathrm{Nd}$ doping is consistent with the larger size of their cations $\left(0.116 \mathrm{~nm}\right.$ for $\mathrm{La}^{3+}$ and $0.112 \mathrm{~nm}$ for $\left.\mathrm{Nd}^{3+}\right)$. These modifications of the cell parameters of ceria upon doping provide evidence that the foreign cations are actually located into the parent ceria framework. However, it cannot be ruled out that, in addition to the amount introduced into the ceria lattice, $\mathrm{Zr}$ was partially segregated, since evidence of such segregated phase was observed in the diffractograms. 
The pore size $(12-17 \mathrm{~nm})$ and pore volume $\left(0.013-0.021 \mathrm{~cm}^{3} / \mathrm{g}\right)$ values are quite similar for all catalysts. The crystallite size of the ceria supports are in the 13-27 $\mathrm{nm}$ range (see Table 1), and the smallest sizes are obtained for undoped and Zr-doped ceria. These two supports also have the largest specific surface areas $\left(58-60 \mathrm{~m}^{2} / \mathrm{g}\right)$, with these values being in good agreement with those typically obtained for cerium oxides exposed to a similar thermal history. ${ }^{20}$ Ceria doping with La, Pr or Nd leads to a decrease of the specific surface area and an increase of the crystallite size, which means that these dopants facilitate sintering. It is known that the effect of dopants on ceria sintering depends on the temperature of the thermal treatments. ${ }^{22}$ As a rule of thumb, dopants partially hinder ceria sintering for high temperature calcination (above $800-900^{\circ} \mathrm{C}$ ) while they have no effect or promote sintering for mild temperature calcination $\left(500-600^{\circ} \mathrm{C}\right)$. The argument postulated to explain such behavior is that the surface defects created upon doping decrease the energy required for crystals to merge, and therefore dopants promote sintering if there are energy restrictions, as occurring at mild temperature. On the contrary, if the temperature is high enough to overcome such energy restrictions to sintering, the effect of dopants is the opposite, partially hindering sintering because they do not allow long-range structural order into the ceria crystals.

Raman spectroscopy (Figure 2) provides additional information about the structure of the catalysts. 


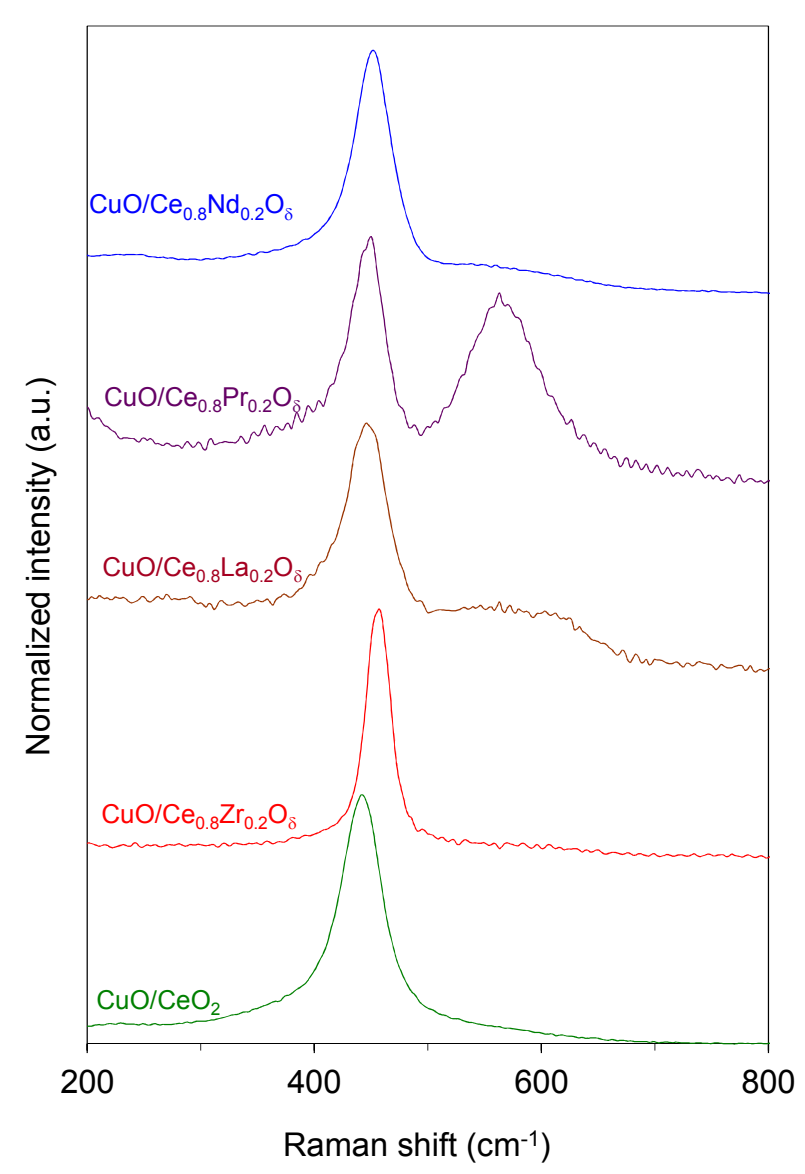

Figure 2. Raman spectra of the catalysts. The spectra were normalized by dividing the intensity of each spectrum between the intensity of its F2g band maximum.

All catalysts show the $F_{2 g}$ band around $450 \mathrm{~cm}^{-1}$, which is a typical feature of the ceria-based oxides. $^{23,24}$ This band has been attributed to the oxygen breathing frequency around the $\mathrm{Ce}^{4+}$ cations. $^{25,26}$ The position of this band provides information about the introduction of foreign cations into the ceria lattice. The position of the $\mathrm{F}_{2 \mathrm{~g}}$ band in pure ceria is usually ca $464 \mathrm{~cm}^{-1},{ }^{20}$ and the position obtained for all $\mathrm{CuO} / \mathrm{Ce}_{0.8} \mathrm{X}_{0.2} \mathrm{O}_{\delta}$ catalysts is well below this value (see data in Table 1). The shift of the $F_{2 g}$ band towards low values is attributed to the presence of foreign 
cations into the lattice larger than $\mathrm{Ce}^{4+}$, while the shift towards high values is assigned to the presence of smaller cations. Therefore, the low values obtained for our catalysts suggest the presence of large cations. In the $\mathrm{CuO} / \mathrm{CeO}_{2}$ catalyst, the large cations could be $\mathrm{Ce}^{3+}$ and a potential explanation would be that the energy of the laser used to obtain the Raman spectra is sufficiently high to partially reduce the surface. Copper seems to play a key role in this reduction, because this effect is not observed in copper-free ceria catalysts. ${ }^{20}$ In catalysts with dopants larger than $\mathrm{Ce}^{4+}$, like $\mathrm{La}^{3+}, \mathrm{Pr}^{3+}$ and $\mathrm{Nd}^{3+}$, the shift of the $\mathrm{F}_{2 \mathrm{~g}}$ band below $464 \mathrm{~cm}^{-1}$ must be additionally attributed to the introduction of such cations into the ceria lattice. It is also reasonable to think that $\mathrm{Ce}^{4+}$ reduction (and also $\operatorname{Pr}^{4+}$ in the case of $\mathrm{CuO} / \mathrm{Ce}{ }_{0.8} \operatorname{Pr}_{0.2} \mathrm{O}_{\delta}$ ) is additionally taking place.

In addition to the $\mathrm{F}_{2 \mathrm{~g}}$ band, another band or shoulder appears in some Raman spectra at 540 $\mathrm{cm}^{-1}$, which has been assigned to oxygen vacancies. The relative intensity of this band with regard to the maximum of the $\mathrm{F}_{2 \mathrm{~g}}$ band is highest for the Pr-containing catalyst, being much lower for the La- or Nd-doped catalysts and negligible for the remaining samples. The formation of oxygen vacancies is expected upon $\mathrm{Ce}^{4+}$ substitution by trivalent cations, like $\mathrm{La}^{3+}$ or $\mathrm{Nd}^{3+}$, while is not expected to be relevant upon isovalent substitution of $\mathrm{Ce}^{4+}$ by $\mathrm{Zr}^{4+}$. The prominent vacants band observed in $\mathrm{CuO} / \mathrm{Ce}_{0.8} \operatorname{Pr}_{0.2} \mathrm{O}_{\delta}$ has been attributed to the easy reduction of the $\operatorname{Pr}^{4+}$ cations, which could be even reduced due to the local heating produced by the laser used to excite the samples and obtain the Raman spectra, as previously reported..$^{21}$ The presence of $\mathrm{Ce}^{3+}$ cations, as previously proposed considering the position of the $F_{2 g}$ band, is also expected to lead to the formation of oxygen vacancies. However, the band due to these vacancies is negligible in spectra of $\mathrm{CuO} / \mathrm{CeO}_{2}$, for instance, suggesting that the partial reduction of $\mathrm{Ce}^{4+}$ under measurements conditions is high enough to shift the position of the $F_{2 g}$ band but not for the band 
due to the vacancies to grow. This is not surprising because, usually, the position of the Raman bands is much more sensitive to changes in the physical chemical features of solids than the intensity of the bands, which is affected by other variables like crystal size or radiation absorption.

In conclusion, these characterization results confirm that, in the $\mathrm{CuO} / \mathrm{Ce}_{0.8} \mathrm{X}_{0.2} \mathrm{O}_{\delta}$ catalysts prepared, the doping cations are actually located into the parent ceria framework. Only the $\mathrm{CuO} / \mathrm{Ce}_{0.8} \mathrm{X}_{0.2} \mathrm{O}_{\delta}$ catalyst shows certain evidences of the formation of a segregated $\mathrm{Zr}$ rich phase, but even in this case, it can be confirmed that part of the $\mathrm{Zr}$ dopant is located into the ceria lattice.

\subsection{Catalysts characterization by $\mathrm{H}_{2}-\mathrm{TPR}$.}

The TCD signals monitored during the $\mathrm{H}_{2}$-TPR experiments are plotted on Figure 3, and all catalysts show a main feature in the $120-300^{\circ} \mathrm{C}$ range, which consist of double peaks or a main peak with a shoulder at low temperature. Also, a small band is shown in some profiles around $800^{\circ} \mathrm{C}$, which can be assigned to the reduction of the particles bulk.

The position of the low-temperature reduction bands indicates that $\mathrm{CuO} / \mathrm{Ce}{ }_{0.8} \mathrm{Zr}_{0.2} \mathrm{O}_{\delta}$ and $\mathrm{CuO} / \mathrm{CeO}_{2}$ are reduced at the lowest temperature, and that the behavior of these two catalysts is quite similar to each other. 


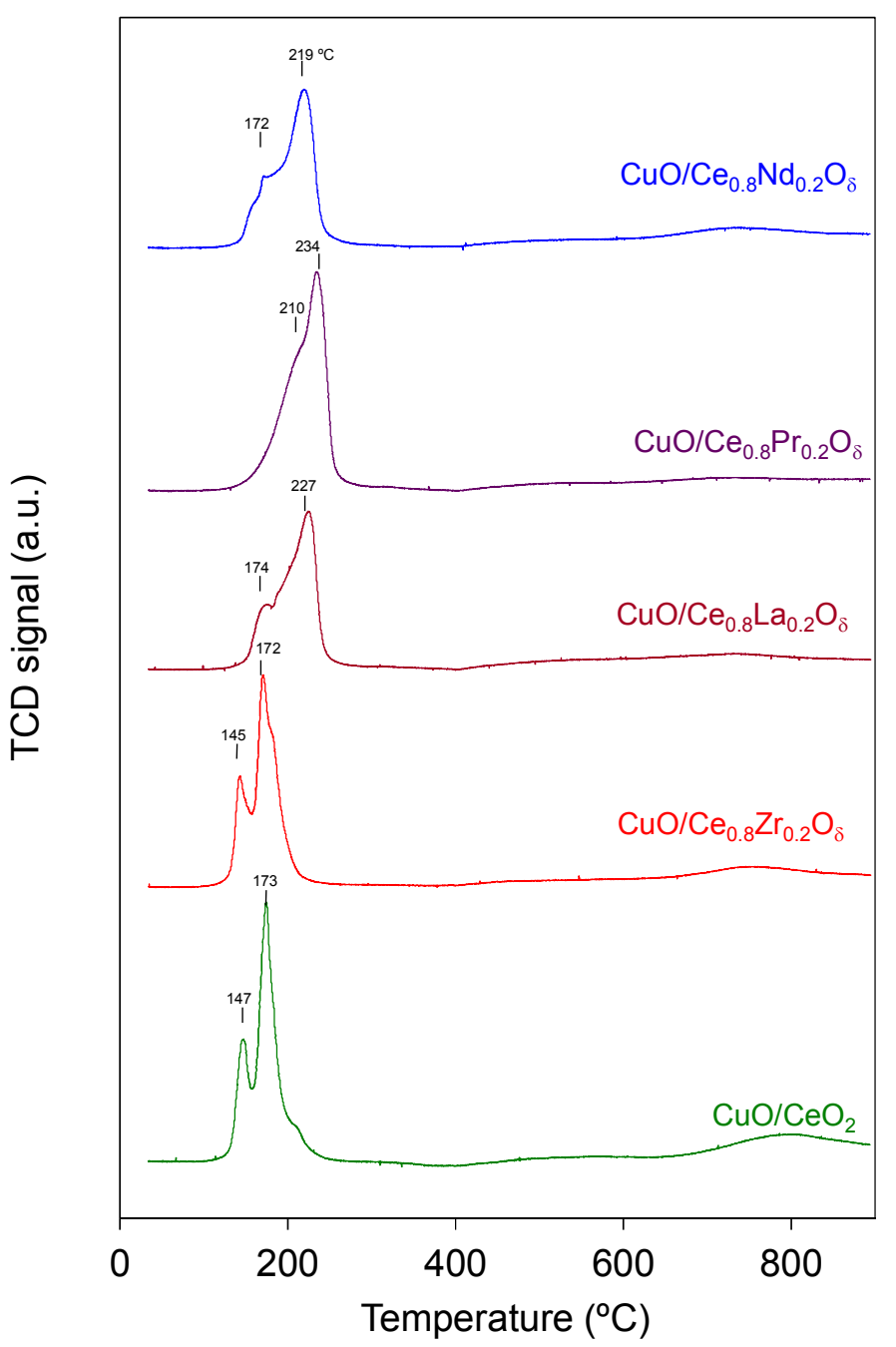

Figure 3. $\mathrm{H}_{2}$-TPR profiles of the catalysts.

Different events are taking place within the reduction bands in the $120-300^{\circ} \mathrm{C}$ range, and the dual-mode shape reported for $\mathrm{MO} / \mathrm{CeO}_{2}$ catalysts $(\mathrm{MO}=$ Metal Oxide) has been related to the reduction of the supported metal oxide (MO) and ceria in close contact with MO at the lowest temperature, and to surface ceria reduction which is not directly in contact with MO at higher temperature. ${ }^{27}$ In the case of $\mathrm{CuO}$ catalysts, the reduction of $\mathrm{Cu}^{2+}$ to $\mathrm{Cu}^{0}$ in two consecutive steps, $\mathrm{Cu}^{2+}$ to $\mathrm{Cu}^{+}$first and $\mathrm{Cu}_{+}$to $\mathrm{Cu}^{0}$ afterwards cannot be ruled out. In the $\mathrm{CuO} / \mathrm{Ce}_{0.8} \operatorname{Pr}_{0.2} \mathrm{O}_{\delta}$ catalyst it must be additionally taken into account that $\operatorname{Pr}^{4+}$ is also reduced to $\operatorname{Pr}^{3+}$. 
Quantitative values calculated from the $\mathrm{H}_{2}$-TPR experiments are compiled in Table 2:

\begin{tabular}{|l|c|c|}
\hline Catalyst & $\mathrm{H}_{2 \text { consumed }} \mathrm{mol} / \mathrm{CuO}$ mol & $\mathrm{Ce}^{4+}$ reduced (\%) \\
\hline $\mathrm{CuO} / \mathrm{CeO}_{2}$ & 1.7 & 20 \\
\hline $\mathrm{CuO} / \mathrm{Ce}_{0.8} \mathrm{Zr}_{0.2} \mathrm{O}_{\delta}$ & 1.6 & 22 \\
\hline $\mathrm{CuO} / \mathrm{Ce}_{0.8} \mathrm{La}_{0.2} \mathrm{O}_{\delta}$ & 1.6 & 23 \\
\hline $\mathrm{CuO} / \mathrm{Ce}_{0.8} \mathrm{Pr}_{0.2} \mathrm{O}_{\delta}$ & 1.9 & $27^{\mathrm{a}}$ \\
\hline $\mathrm{CuO} / \mathrm{Ce}_{0.8} \mathrm{Nd}_{0.2} \mathrm{O}_{\delta}$ & 1.8 & 28 \\
\hline
\end{tabular}

Table 2. Quantitative values calculated from the $\mathrm{H}_{2}$-TPR experiments.

${ }^{\mathrm{a}}$ In the $\mathrm{CuO} / \mathrm{Ce}_{0.8} \mathrm{Pr}_{0.2} \mathrm{O}_{\delta}$ catalyst, the percentage of $\mathrm{Ce}^{4+}$ reduced is actually $\mathrm{Ce}^{4+}+\mathrm{Pr}^{4+}$.

In all cases, the moles of $\mathrm{H}_{2}$ consumed are higher than those of $\mathrm{CuO}$ on the catalysts, and this provides experimental evidence that not only is $\mathrm{CuO}$ being reduced but also the ceria supports. Considering total reduction of $\mathrm{Cu}^{2+}$ to $\mathrm{Cu}^{0}$, the percentages of $\mathrm{Ce}^{4+}$ reduced to $\mathrm{Ce}^{3+}$ are in the 20$28 \%$ range for all catalysts.

These $\mathrm{H}_{2}$-TPR experiments allow concluding that the presence of dopants affect the reducibility of the $\mathrm{CuO}-\mathrm{Ceria}$ system, and $\mathrm{CuO} / \mathrm{Ce}_{0.8} \mathrm{Zr}_{0.2} \mathrm{O}_{\delta}$ and $\mathrm{CuO} / \mathrm{CeO}_{2}$ are reduced more easily than the remaining catalysts. This affects the temperature required for catalysts reduction by $\mathrm{H}_{2}$, but differences in the extent of the reduction are not very relevant once totally accomplished.

\subsection{Catalytic tests in a fixed-bed reactor.}

Figure 4 shows the oxidation of $\mathrm{CO}$ (Figure 4a) and the $\mathrm{CO}$ selectivity (Figure $4 \mathrm{~b}$ ) obtained in the fixed-bed reactor PROX experiments, where it is observed that the catalysts with the undoped and Zr-doped supports are active and selective at lower temperature than catalysts containing La, Pr or Nd. Four consecutive experiments were carried out with the most active 
catalysts $\left(\mathrm{CuO} / \mathrm{Ce}_{0.8} \mathrm{Zr}_{0.2} \mathrm{O}_{\delta}\right.$ and $\left.\mathrm{CuO} / \mathrm{CeO}_{2}\right)$ and reproducible $\mathrm{CO}$ conversion and selectivity profiles were obtained, confirming the high stability of these catalysts under reaction conditions. Isothermal experiments were also performed at $120^{\circ} \mathrm{C}$ and constant $\mathrm{CO}$ conversion and selectivity values were kept for 12 hours. All these curves are included in the supplementary material.
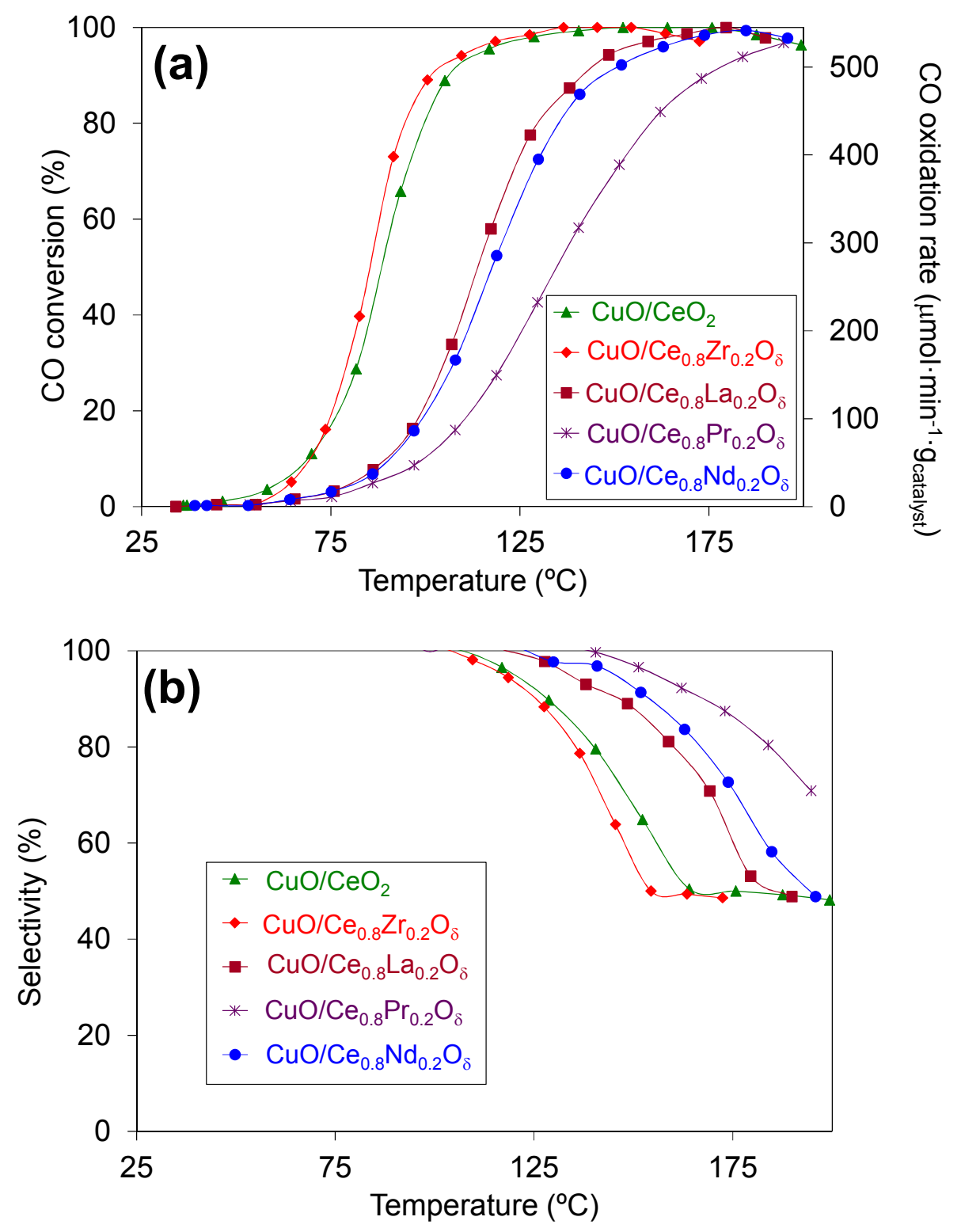
Figure 4. CO-PROX reactions performed in a fixed-bed reactor. (a) CO conversion and oxidation rate and (b) $\mathrm{CO}$ selectivity.

The results on Figure 4, together with the previous $\mathrm{H}_{2}$-TPR characterization, confirm that the reducibility of the catalyst plays an important role in $\mathrm{CO}$ oxidation, since the catalytic processes are based on redox cycles taking place on the catalyst surface. In accordance with the well accepted role of the different copper species in the PROX reactions, ${ }^{15-17}$ the oxidation of CO starts at temperatures $\left(\sim 50^{\circ} \mathrm{C}\right)$ lower than those required for the extensive reduction of the catalyst surface by $\mathrm{H}_{2}$ (see $\mathrm{H}_{2}$-TPR in Figure 3). This is in agreement with the hypothesis supporting that the active sites for $\mathrm{CO}$ oxidation are $\mathrm{Cu}^{+}$sites located at the $\mathrm{CuO}$-Ceria interface. In addition, the selectivity drops (Figure 4b) when temperature approaches the onset temperature for extensive reduction of the catalysts surface (see $\mathrm{H}_{2}$-TPR in Figure 3), supporting that $\mathrm{H}_{2}$ oxidation takes place on reduced metal sites.

\subsection{Operando DRIFTS-MS experiments.}

In order to investigate the nature of the carbon intermediates and to determine whether hydroxyl groups on the catalyst play a critical role in the formation of bicarbonates and in the CO oxidation rate, operando DRIFTS-MS experiments were carried out.

Figure 5 shows, as representative examples, spectra obtained with $\mathrm{CuO} / \mathrm{Ce}_{0.8} \mathrm{Zr}_{0.2} \mathrm{O}_{\delta}$ and $\mathrm{CuO} / \mathrm{Ce}_{0.8} \mathrm{La}_{0.2} \mathrm{O}_{\delta}$. DRIFT spectra were recorded between $4000-1000 \mathrm{~cm}^{-1}$, but the main features are located in three main regions. Figures $5 \mathrm{a}$ and $5 \mathrm{~d}$ show the $1650-1150 \mathrm{~cm}^{-1}$ range, where several vibration/stretching modes corresponding to carbonates, bicarbonates and formates are 
identified. Figures $5 \mathrm{~b}$ and $5 \mathrm{e}$ show the $2250-1950 \mathrm{~cm}^{-1}$ range, where a single band corresponding to the $\mathrm{Cu}^{+}-\mathrm{CO}$ carbonyl is observed. Figures $5 \mathrm{c}$ and $5 \mathrm{~d}$ show the $3850-2450 \mathrm{~cm}^{-1}$ range, where hydroxyl groups are detected..
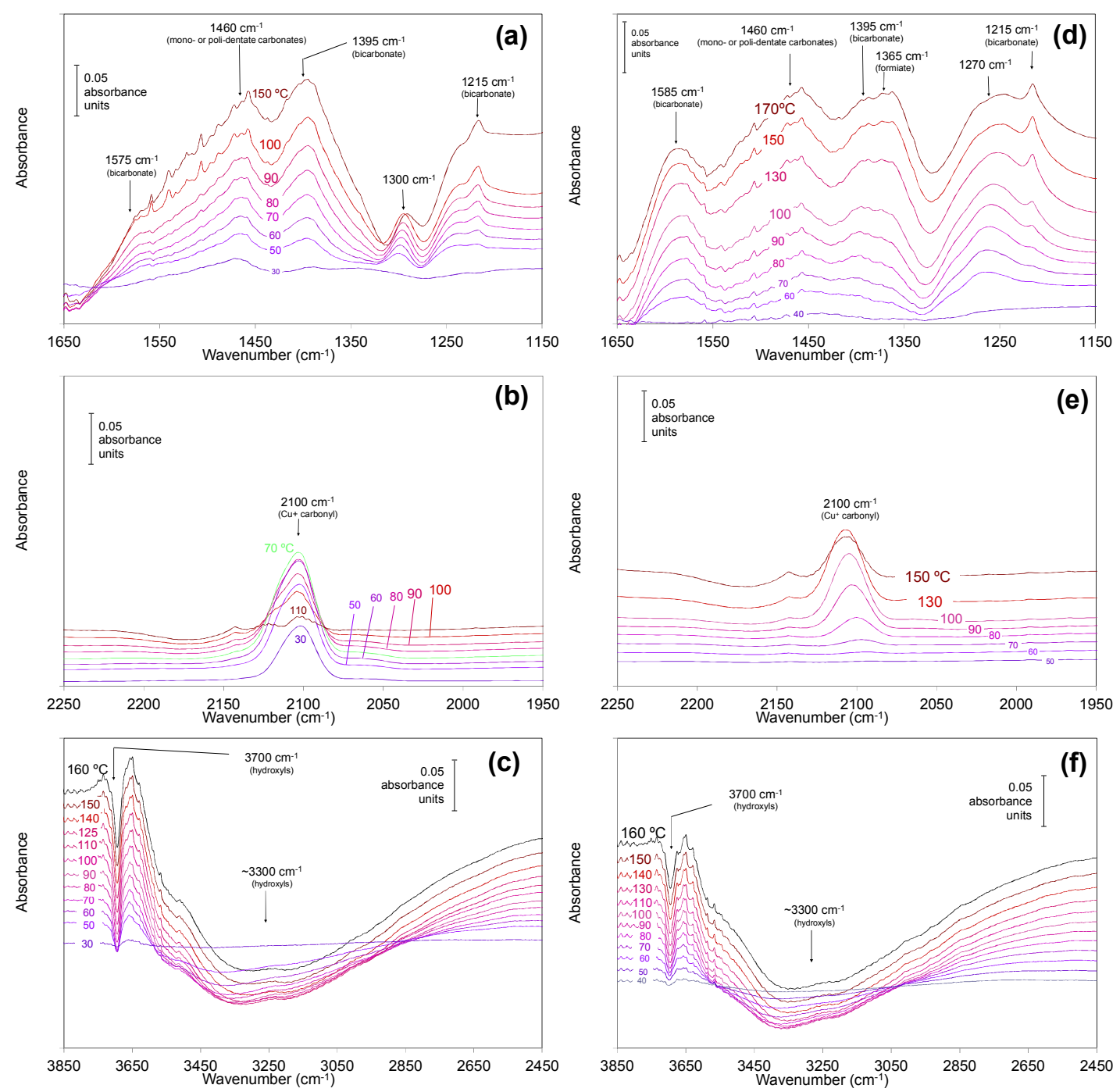

Figure 5. DRIFT spectra as a function of temperature under operando PROX conditions with $\mathrm{CuO} / \mathrm{Ce}_{0.8} \mathrm{Zr}_{0.2} \mathrm{O}_{\delta}\left(\mathrm{a}, \mathrm{b}\right.$ and $\mathrm{c}$ ) and $\mathrm{CuO} / \mathrm{Ce}_{0.8} \mathrm{La}_{0.2} \mathrm{O}_{\delta}(\mathrm{d}$, e and $\mathrm{f}$ ). 


\subsubsection{Role of the catalyst hydroxyls groups}

The main carbon-containing reaction intermediates accumulated on the catalysts surface during the PROX reaction are carbonates and bicarbonates, as is observed in the DRIFT spectra (Figure 5). Figure 6 shows the ratio between the band maxima due to bicarbonates (at $1395 \mathrm{~cm}^{-1}$ ) and carbonates (at $1460 \mathrm{~cm}^{-1}$ ) as a function of temperature for all catalysts.

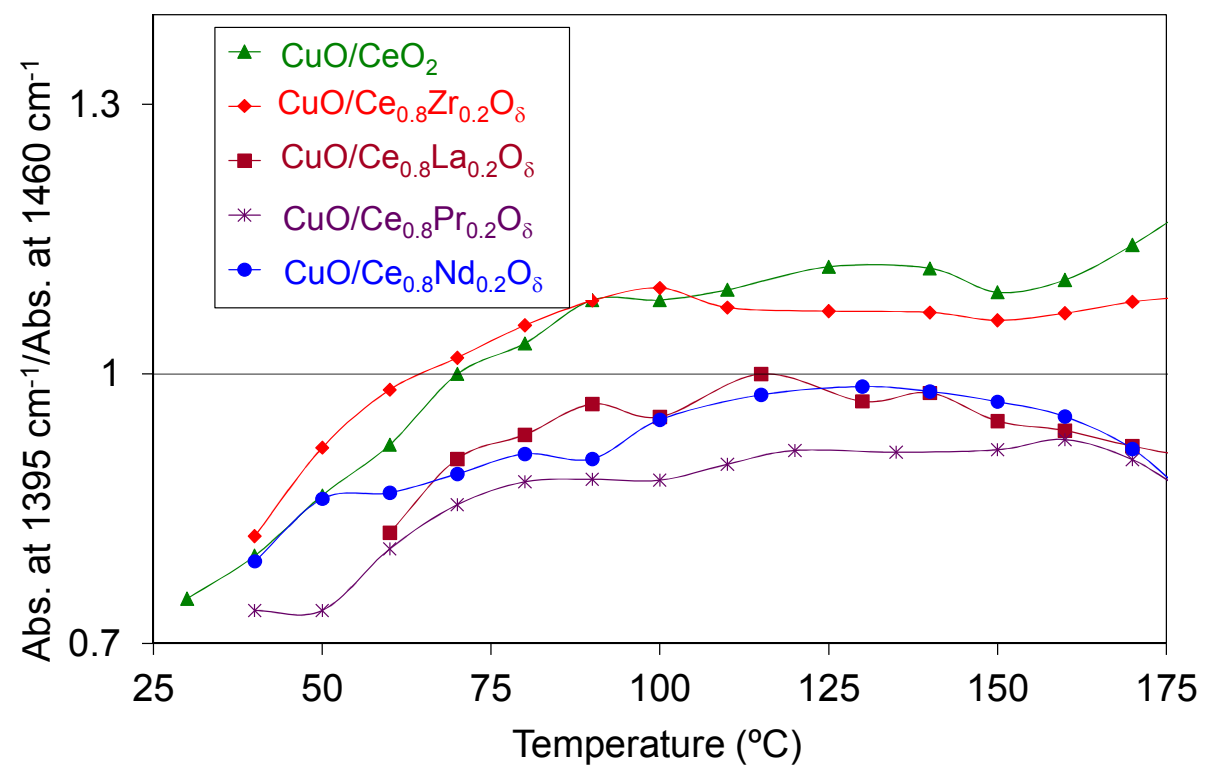

Figure 6. Ratio between the absorbance at $1395 \mathrm{~cm}^{-1}$ (bicarbonates) and the absorbance and $1460 \mathrm{~cm}^{-1}$ (carbonates) as a function of temperature.

The most active catalysts $\left(\mathrm{CuO} / \mathrm{CeO}_{2}\right.$ and $\left.\mathrm{CuO} / \mathrm{Ce}_{0.8} \mathrm{Zr}_{0.2} \mathrm{O}_{\delta}\right)$ favor the formation of surface bicarbonates in preference of carbonates, while catalysts with lower CO-PROX activity $(\mathrm{X}=\mathrm{La}$, $\operatorname{Pr}$ or $\mathrm{Nd}$ ) accumulate more carbonates on the surface. It is known that the accumulation of carbon-containing species on $\mathrm{CuO} / \mathrm{CeO}_{2}$ PROX catalysts decreases the activity due to blockage 
of active sites. ${ }^{28}$ The positive effect on the $\mathrm{CO}$ oxidation rate of the presence of surface bicarbonates as adsorbed species with regards to carbonates could be related to the lower thermal stability of the former species, which would lead to a faster desorption of $\mathrm{CO}_{2}$ leaving the surface available for further chemisorption of other potential species which might act as reaction intermediates. However, there is no experimental evidence to support this hypothesis, and it could also be possible that $\mathrm{CO}_{2}$ produced at $\mathrm{CuO}$-Ceria actives sites is transferred to hydroxyls in a further step, leaving the actives sites available again. In any case, formation of bicarbonates in preference to carbonates seems positive for $\mathrm{CO}$ oxidation.

Catalysts hydroxyls are involved in the formation of surface bicarbonates, as it is deduced from Figure 7 where the intensity of the bicarbonates band at $1395 \mathrm{~cm}^{-1}$ is plotted as a function of the area of the hydroxyls band $\left(3600-2500 \mathrm{~cm}^{-1}\right.$ range). Note that the area of the hydroxyls band shows negative values because hydroxyls are consumed during the reactions. Linear relationships between the consumption of hydroxyls and the formation of bicarbonates are observed for all catalysts suggesting that the two processes are related to each other.

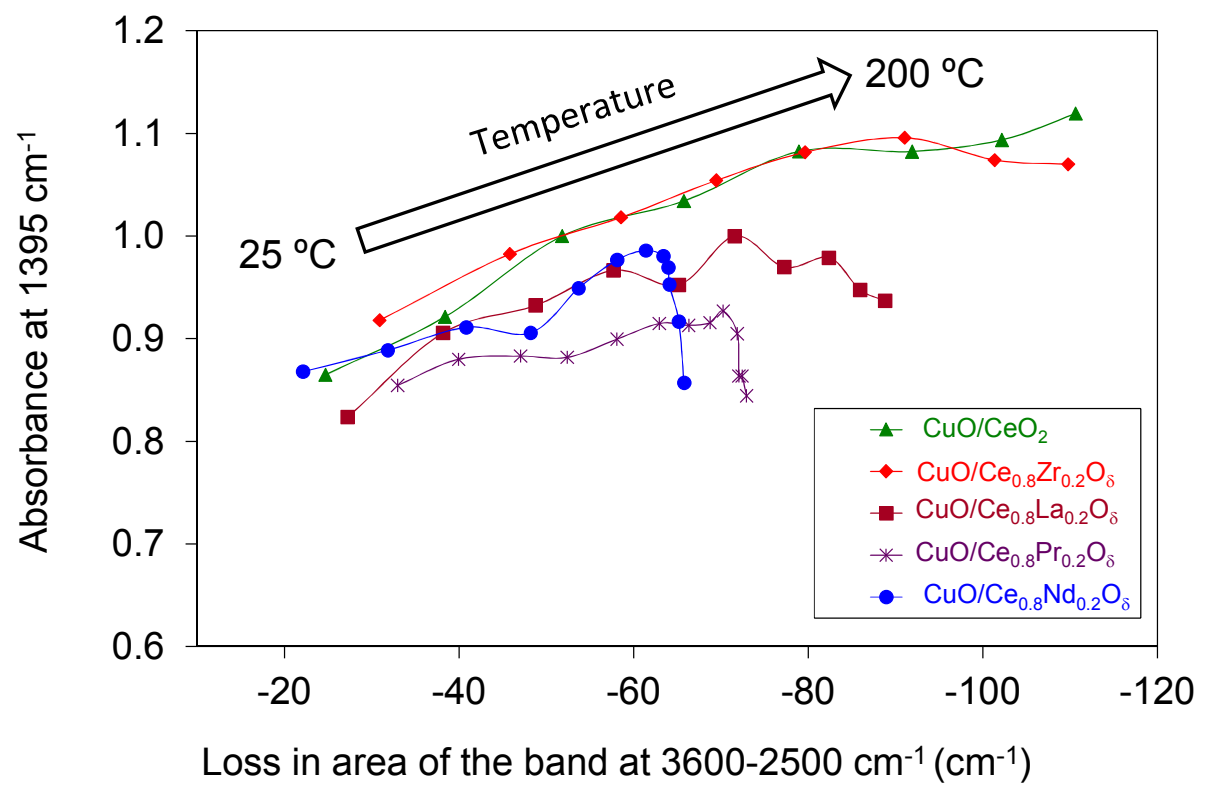


Figure 7. Relationship between bicarbonate formation (band at $1395 \mathrm{~cm}^{-1}$ ) and hydroxyl consumption (band in the $2500-3600 \mathrm{~cm}^{-1}$ range).

Figure 7 also shows that the linear trend holds for the whole range of temperatures studied (25$\left.200{ }^{\circ} \mathrm{C}\right)$ for the most active catalysts $\left(\mathrm{CuO} / \mathrm{CeO}_{2}\right.$ and $\left.\mathrm{CuO} / \mathrm{Ce}_{0.8} \mathrm{Zr}_{0.2} \mathrm{O}_{\delta}\right)$ but not for those with lower activity $(\mathrm{X}=\mathrm{La}$, Pr or $\mathrm{Nd})$. Catalysts with $\mathrm{X}=\mathrm{La}$, Pr or $\mathrm{Nd}$ show a deviation from the trend line of Figure 7 above a certain temperature, and according to results in Figure $4 b$, this deviation occurs at a stage where the $\mathrm{CO}$ selectivity decreases, that is, where the onset of $\mathrm{H}_{2}$ oxidation begin. A vertical drop in Figure 7 indicates that the amount of surface hydroxyls remains constant above a certain temperature while surface bicarbonates are depleted.

According to these results and the background literature, our proposed $\mathrm{CO}$ oxidation mechanism is as follows:

$$
\begin{array}{lr}
2 \mathrm{CuO}+\mathrm{CO} \rightarrow \mathrm{Cu}_{2} \mathrm{O}-\mathrm{O}-\mathrm{CO} & \text { step } 1 \\
\mathrm{Cu}_{2} \mathrm{O}-\mathrm{O}-\mathrm{CO}+*_{-} \mathrm{O} \rightarrow \mathrm{Cu}_{2} \mathrm{O}+*_{-} \mathrm{CO}_{3} & \text { step } 2 \mathrm{a} \\
\mathrm{Cu}_{2} \mathrm{O}-\mathrm{O}-\mathrm{CO}+*_{-} \mathrm{OH} \rightarrow \mathrm{Cu}_{2} \mathrm{O}+*_{-} \mathrm{CO}_{2} \mathrm{OH} & \text { step } 2 \mathrm{~b} \\
\mathrm{Cu}_{2} \mathrm{O}+1 / 2 \mathrm{O}_{2} \rightarrow 2 \mathrm{CuO} & \text { step 3 } \\
*_{-} \mathrm{CO}_{3} \rightarrow *-\mathrm{O}+\mathrm{CO}_{2} & \text { step 4a } \\
*_{-} \mathrm{CO}_{2} \mathrm{OH} \rightarrow *_{-} \mathrm{OH}+\mathrm{CO}_{2} & \text { step 4b }
\end{array}
$$

where $\mathrm{CuO}$ are active sites for $\mathrm{CO}$ chemisorption at the copper oxide-cerium oxide interface, $\mathrm{Cu}_{2} \mathrm{O}-\mathrm{O}-\mathrm{CO}$ represents the $\mathrm{Cu}^{+}-\mathrm{CO}$ carbonyl, *-O are chemisorption sites where surface carbonates $\left(*_{-} \mathrm{CO}_{3}\right)$ are formed and $*_{-} \mathrm{OH}$ are chemisorption sites where surface bicarbonates $\left(*_{-}\right.$ $\left.\mathrm{CO}_{2} \mathrm{OH}\right)$ are formed. 
The CO oxidation reaction mechanism starts with $\mathrm{CO}$ chemisorption at the copper oxidecerium oxide interface and formation $\mathrm{Cu}^{+}-\mathrm{CO}$ carbonyls (step 1), and it has been proposed that chemisorbed $\mathrm{CO}$ is oxidized to $\mathrm{CO}_{2}$ following a Mars van Krevelen mechanism using the $\mathrm{Cu}^{2+} / \mathrm{Cu}^{+}$redox cycle. ${ }^{15}$ Then, $\mathrm{CO}_{2}$ is transferred from the copper oxide-cerium oxide interface to other surface sites, probably on the ceria support, forming bicarbonates (step 2a) and carbonates (step 2b), and molecular oxygen reoxidizes the reduced sites via steps 3. Surface hydroxyls are involved in the formation of bicarbonates (step 2b). Finally, $\mathrm{CO}_{2}$ is desorbed following steps $4 \mathrm{a}$ and $4 b$.

\subsubsection{Product poisoning versus $\mathrm{Cu}^{+}-\mathrm{CO}$ carbonyl}

The contribution to the $\mathrm{CO}$ oxidation rate of the copper oxide-cerium oxide interface reducibility and of the carbon products desorption has been analyzed.

Figure 8 shows the area of the $\mathrm{Cu}^{+}-\mathrm{CO}$ carbonyl peak monitored under CO-PROX reaction conditions for all $\mathrm{CuO} / \mathrm{Ce}_{0.8} \mathrm{X}_{0.2} \mathrm{O}_{\delta}$ catalysts as a function of the reaction temperature, where it is observed that the room temperature formation of the $\mathrm{Cu}^{+}-\mathrm{CO}$ carbonyl obtained with the $\mathrm{Zr}$ containing catalyst is about three times higher to that formed on the undoped $\mathrm{CuO} / \mathrm{CeO}_{2}$ counterpart, and that the $\mathrm{Cu}^{+}-\mathrm{CO}$ carbonyl formation is delayed to higher temperatures for catalysts with $\mathrm{X}=\mathrm{La}$, Pr or $\mathrm{Nd}$. 


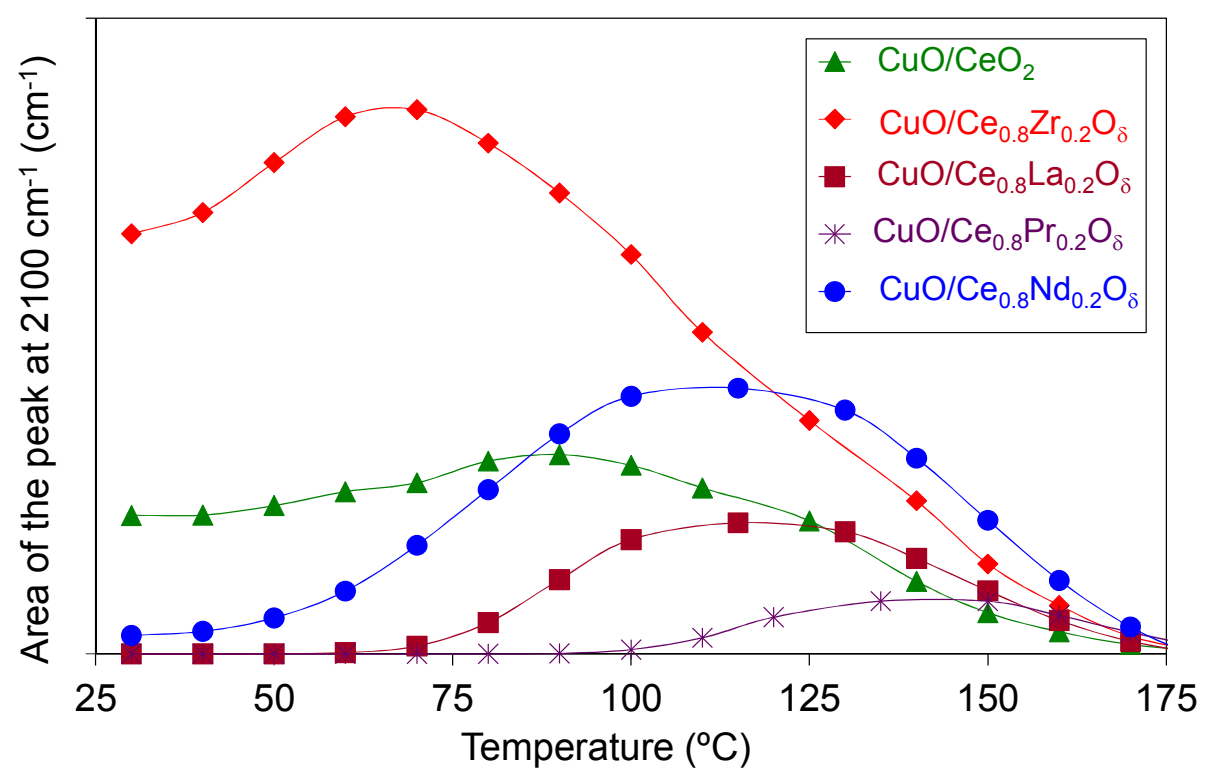

Figure 8. Integrated area of the $\mathrm{Cu}^{+}-\mathrm{CO}$ carbonyl band at $2100 \mathrm{~cm}^{-1}$ as a function of the reaction temperature.

The temperature of maximum carbonyl coverage has been determined from Figure 8 , and this temperatures correlate to the $\mathrm{CO}$ oxidation rates. Figure 9 shows the relationship between the $\mathrm{CO}$ oxidation rate and the formation of the $\mathrm{Cu}^{+}-\mathrm{CO}$ carbonyl in the CO-PROX experiments. The data for most $\mathrm{CuO} / \mathrm{Ce}_{0.8} \mathrm{X}_{0.2} \mathrm{O}_{\delta}$ catalysts lie on a straight line, confirming the important role of the reducibility of the copper oxide-cerium oxide interface. ${ }^{15,16}$ 




Figure 9. Relationship between temperature required to attain a certain $\mathrm{CO}$ oxidation rate and temperature corresponding to the maximum absorbance due to $\mathrm{Cu}^{+}-\mathrm{CO}$ carbonyl.

However, the $\mathrm{CO}$ oxidation rate obtained with the $\mathrm{Zr}$-containing catalyst is lower than that predicted by its $\mathrm{Cu}^{+}-\mathrm{CO}$ carbonyl population. These results indicate that the $\mathrm{Cu}^{+}-\mathrm{CO}$ carbonyl formation (step 1) is the rate limiting step for temperatures above a certain threshold (above 90 ${ }^{\circ} \mathrm{C}$ approximately for the experimental conditions of this study) but, below this temperature, the accumulation of reaction products on the catalyst surface must also be taken into account because decomposition of reaction intermediates (steps $4 \mathrm{a}$ and $4 \mathrm{~b}$ ) becomes the slowest step of the mechanism. Therefore, the nature of the carbon species accumulated on the catalyst (bicarbonates or carbonates) should be mainly relevant below this temperature $\left(90^{\circ} \mathrm{C}\right)$.

The area of a broad DRIFTS band envelope with several contributions appearing in the 1650$1300 \mathrm{~cm}^{-1}$ range has been calculated. This band can be attributed to surface carbonates and 
bicarbonates (and formates in particular cases). Figure 10 shows the area of this band as a function of the reaction temperature for all catalysts.

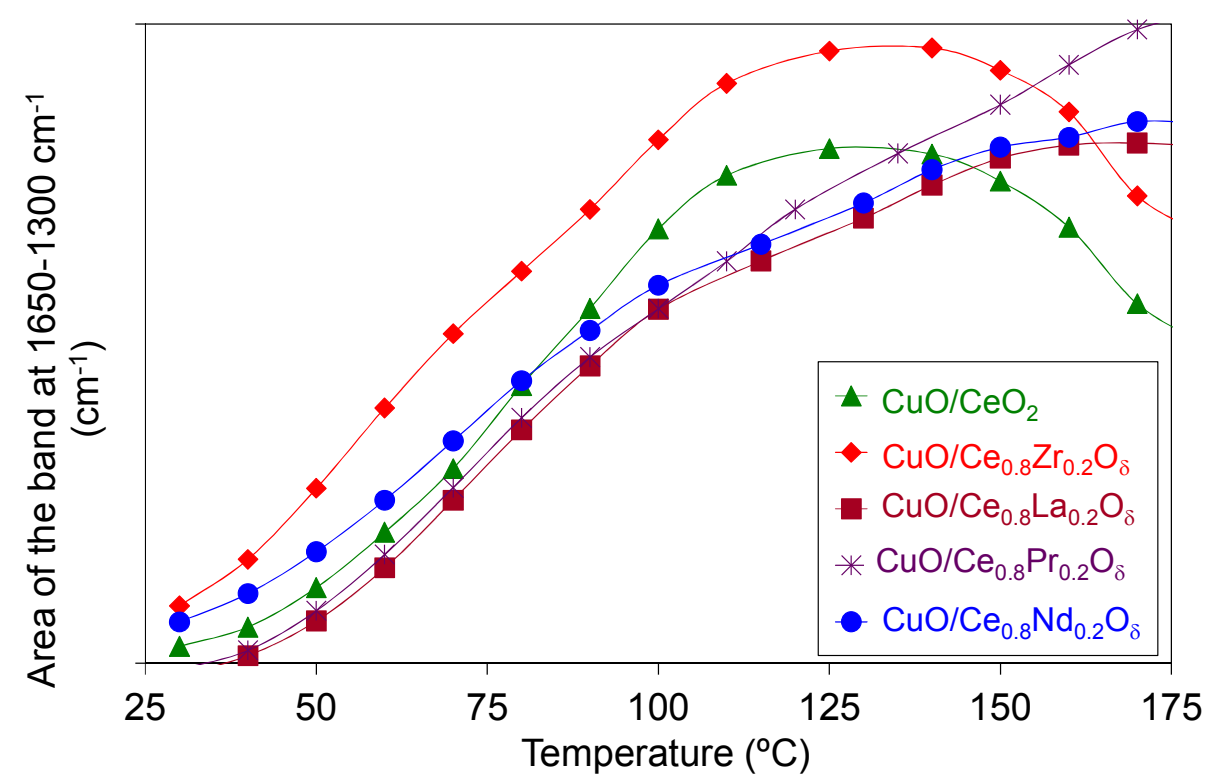

Figure 10. Integrated area of the band due to carbon containing products (carbonates + bicarbonates + formates) in the $1650-1300 \mathrm{~cm}^{-1}$ range as a function of the reaction temperature.

The accumulation of carbon containing reaction products is highest for the Zr-containing catalyst, its area of the $1650-1300 \mathrm{~cm}^{-1}$ band being, for instance, twice that of $\mathrm{CuO} / \mathrm{CeO}_{2}$ at 50 ${ }^{\circ} \mathrm{C}$. The poisoning by the formation of carbon containing adsorbed intermediates explains why the $\mathrm{CO}$ oxidation rate of the $\mathrm{CuO} / \mathrm{Ce}_{0.8} \mathrm{Zr}_{0.2} \mathrm{O}_{\delta}$ catalyst does not follow the trend predicted by the formation of the $\mathrm{Cu}^{+}-\mathrm{CO}$ carbonyl (Figure 9). Comparison of the $\mathrm{CuO} / \mathrm{CeO}_{2}$ and $\mathrm{CuO} / \mathrm{Ce}_{0.8} \mathrm{Zr}_{0.2} \mathrm{O}_{\delta}$ behavior is interesting because both catalysts show similar CO-PROX activity, 
the latter more readily forming the $\mathrm{Cu}^{+}-\mathrm{CO}$ carbonyl at low temperature but also suffering much stronger inhibition by adsorbed products. Therefore, the contribution to the $\mathrm{CO}$ oxidation rate of the $\mathrm{Cu}^{+}-\mathrm{CO}$ carbonyl formation and carbon products desorption oppose each other at low temperature. Taking the trend of Figure 9 into account, poisoning by reaction products becomes of special relevance at temperatures below ca. $90{ }^{\circ} \mathrm{C}$ for the experimental conditions used in this study.

The CO-PROX experiments performed in this study show that ceria doping with foreign cations has either no effect or a negative impact on the activity, and this observation has been also reported by many authors. ${ }^{29}$ There have been only reported few examples of improved COPROX activity of copper oxide-cerium oxide activity upon ceria doping, ${ }^{30-32}$ but the reasoning why some authors observe the positive effect of ceria doping while most do not has not been fully explained. It has been proposed that the incorporation of foreign cations into the ceria lattice hinders the extent of copper oxide-cerium oxide interaction and it is this interface where the most active sites for $\mathrm{CO}$ oxidation are located. ${ }^{33}$ Temperature programmed reduction experiments performed with $\mathrm{H}_{2}$, (Figure 3), also indicate that the onset reduction temperature is lowest for the most active catalysts in the $\mathrm{CO}-\mathrm{PROX}$ reaction $\left(\mathrm{CuO} / \mathrm{CeO}_{2}\right.$ and $\left.\mathrm{CuO} / \mathrm{Ce}_{0.8} \mathrm{Zr}_{0.2} \mathrm{O}_{\delta}\right)$, that is, most dopants $(\mathrm{X}=\mathrm{La}$, Pr or $\mathrm{Nd}$ ) retard $\mathrm{CO}$ oxidation with regard to $\mathrm{CuO} / \mathrm{CeO}_{2}$ and $\mathrm{CuO} / \mathrm{Ce}_{0.8} \mathrm{Zr}_{0.2} \mathrm{O}_{\delta}$ because they delay the onset in the reduction temperature.

\subsubsection{Comparing CO-PROX with other catalytic reactions}

The observed lack of influence or negative effect of ceria doping in the CO-PROX activity is in disagreement with the general behavior of ceria in most catalyzed reactions, such as in Three 
Way Catalysts (TWC) where ceria doping by $\mathrm{Zr}^{4+}$ enhances the oxygen storage capacity, the redox properties, and overall, the catalytic performance. ${ }^{34}$ The positive effect of ceria doping has been also reported for ceria-catalyzed diesel soot combustion ${ }^{35,36}$ or NOx storage and Reduction (NSR) on Pt/Ceria catalysts, ${ }^{37}$ for instance, where the redox properties of ceria play an important role.

An important difference between the CO-PROX reaction and the other applications where the doping of ceria has a positive effect is the range of temperatures where the reactions take place. Ceria doping with foreign cations usually has a positive effect on the activity for catalytic applications occurring at medium or high temperatures (around $200-300^{\circ} \mathrm{C}$ for $\mathrm{TWC}$ and NSR or $>400{ }^{\circ} \mathrm{C}$ for soot combustion, for instance). Dopants improve the thermal stability, oxygen storage capacity and/or some other physic-chemical properties of the ceria-based oxide, and therefore the catalytic activity, but the potential stabilization of the reaction intermediates on the catalyst has a minor effect on the reaction rate because the temperature is high enough to encourage desorption of the reaction products. On the other hand, the CO-PROX reaction takes place below ca $100^{\circ} \mathrm{C}$, and desorption of reaction products becomes a critical step. Therefore, the challenge for CO-PROX is to prepare copper oxide-cerium oxide catalysts which are readily reducible at low temperature but that, at the same time, also desorb the reaction products at low temperature, and the participation of catalyst hydroxyls in the formation of bicarbonates as reaction intermediates has a positive effect.

\section{4.- Conclusions}


The CO oxidation rate accelerated by copper oxide-cerium oxide catalysts in CO-PROX conditions correlates with the formation of the $\mathrm{Cu}^{+}-\mathrm{CO}$ carbonyl above a critical temperature $\left(90^{\circ} \mathrm{C}\right.$ for the experimental conditions of this study) because step 1 (copper carbonyl formation) is the rate limiting step. However, desorption of carbon containing products (steps $4 \mathrm{a}$ and $4 \mathrm{~b}$ ) is the slowest step below this threshold temperature. The hydroxyl groups on the catalyst surface play a key role in determining the nature of the carbon-based intermediates formed upon $\mathrm{CO}$ chemisorption and oxidation. Hydroxyls favor the formation of bicarbonates with respect to carbonates, and catalyst which preferentially form bicarbonates attain faster $\mathrm{CO}$ oxidation rates than those which favor carbonates.

\section{Acknowledgments}

The authors thank the financial support of Generalitat Valenciana (Project PROMETEOII/2014/010 and grant BEST/2014/250), the Spanish Ministry of Economy and Competitiveness (Projects CTQ2012-30703, CTQ2012-31762, MAT2014-61992-EXP and grant PRX14/00249), and the UE (FEDER funding).

Supporting Information. Consecutive catalytic tests in a fixed-bed reactor; selected $\mathrm{m} / \mathrm{z}$ signals recorded during operando DRIFTS-MS experiments. This material is available free of charge via the Internet at http://pubs.acs.org.

\section{Corresponding Author}

*Inorganic Chemistry Department; University of Alicante. Carretera de San Vicente s/n. E03080, Alicante (Spain).Tel. (+34) 965903538; Fax. (+34) 965903454. Email: agus@ua.es

\section{Author Contributions}


The manuscript was written by contributions from all authors. All authors have given their approval to the final version of the manuscript. All authors contributed equally.

1

2

5

6

7

8

9

10

11

12

13

14

15

16

17

18

19

20

21

22

23

24

25

26

27

28

29

30

31

32

33

34

35

36

37

38

39

40

41

42

43

44

45

46

47

48

49

50

51

52

53

54

55

56

57

58

59

60 


\section{References}

[1] Ghenciu, A. F. Curr. Opin. Solid. St. M. 2002, 6, 389-399.

[2] Park, E.D.; Lee, D.; Lee, H.C. Catal. Today 2009, 139, 280-290.

[3] Fu, Q.; Saltsburg, H.; Flytzani-Stephanopoulos, H. Science 2003, 301, 935-938.

[4] Ko, E.-Y.; Park, E. D.; Lee, H. C.; Lee D.; Kim, S. Angew. Chem., Int. Ed. 2007, 46, 734737.

[5] Hornes, A.; Hungria, A. B.; Bera, P.; Lopez Cámara, A.; Fernandez-Garcia, M.; MartinezArias, A.; Barrio, L.; Estrella, M.; Zhou, G.; Fonseca, J. J.; Hanson, J. C.; Rodriguez, J. A. J. Am. Chem. Soc. 2010, 132, 34-35.

[6] Tada, M.; Bal, R.; Mu, X.; Coquet, R.; Namba, S.; Iwasawa, Y. Chem. Commun. 2007, 44, 4689-4691.

[7] Sedmak, G.; Hočevar, S.; Levec, J. J. Catal. 2003, 213, 135-150.

[8] Wang, W.W.; Du, P.P.; Zou, S.H.; He, H.Y.; Wang, R.X.; Jin, Z.; Shi, S.; Huang, Y.Y.; Si, R.; Song, Q.S.; Jia, C.J.; Yan, C.H. ACS Catal. 2015, 5, 2088-2099.

[9] Guzman, J.; Carrettin, S.; Corma, A. J. Am. Chem. Soc. 2005, 127, 3286-3287.

[10] Deng, W.; Flytzani-Stephanopoulos, M. Angew. Chem., Int. Ed. 2006 45, 2285-2289.

[11] Alayoglu S.; Eichhorn, B. J. Am. Chem. Soc. 2008, 130, 17479-17486. 
[12] Nilekar, A.U.; Alayoglu, S.; Eichhorn, B.; Mavrikakis, M. J. Am. Chem. Soc. 2010, 132, 7418- 7428.

[13] Morfin, F.; Nassreddine, S.; Rousset, J.L., Piccolo, L. ACS Catal. 2012, 2, 2161-2168.

[14] Zhang, R.; Haddadin, T.; Rubiano, D. P.; Nair, H.; Polster, C. S.; Baertsch, C. D. ACS Catal. 2011, 1, 519-525.

[15] Gamarra, D.; Belver, C.; Fernández-García, M.; Martínez-Arias, A. J. Am. Chem. Soc. 2007, 129, 12064-12065

[16] Martínez-Arias, A.; Hungría, A. B.; Fernández-García, M.; Iglesias-Juez, A.; Soria, J.; Conesa, J. C.; Anderson, J. A.; Munuera, G. Phys. Chem. Chem. Phys. 2012, 14 21442151.

[17] Polster, C. S.; Nair, H.; Baertsch, C. D. J. Catal. 2009, 266, 308-319.

[18] Liu, K.; Wang, A.; Zhang, T. ACS Catal. 2012, 2, 1165-1178.

[19] van Berkum, J. G. M.; Delhez, R.; de Keijser, Th. H.; Mittemeijer, E. J. Acta Cryst. 1996, A52, 730-747.

[20] Guillén-Hurtado, N.; Bueno-López, A.; García-García. A. J. Mater. Sci. 2012, 47, 32043213.

[21] Krishna, K.; Bueno-López, A.; Makkee, M.; Moulijn. J.A. Appl. Catal. B Env. 75, 2007, $189-200$. 
[22] Bueno-López, A.; Such-Basáñez, I.; Salinas-Martínez de Lecea, C. J. Catal. 2006, 244, 102-112.

[23] Ikryannikova, L.N.; Aksenov, A.A.; Markaryan, G.L.; Muraveva, G.P.; Kostyuk, B.G.; Kharlanov, A.N.; Lunina, E.V. Appl. Catal. A Gen. 2001, 210, 225-235.

[24] Mineshige, A.; Taji, T.; Muroi, Y.; Kobune, M.; Fujii, S.; Nishi, N.; Inaba, M.; Ogumi, Z. Solid State Ionics 2000, 135, 481-485.

[25] Mcbride, J.R.; Hass, K.C.; Poindexter, B.D.; Weber, W.H. J. Appl. Phys. 1994, 76, 24352441.

[26] Spanier, J.E.; Richard, R.D.; Robinson, D.; Zhang, F.; Chan, S.-W.; Herman, I.P. Phys. Rev. B 2001, 64, 245407-245407-8.

[27] Fornasiero, P.; Di Monte, R.; Rao, G.R.; Kaspar, J.; Meriani, S.; Trovarelli, A.; Graziani, M. J. Catal. 1995, 151, 168-177.

[28] Gamarra, D.; Martínez-Arias, A. J. Catal. 2009, 263, 189-195.

[29] López, I.; Valdés-Solís, T.; Marbán, G. Int. J. Hydrogen Energ. 2008, 33, 197-205.

[30] Santos Moura, J.; da Silva Lima Fonseca, J.; Bion, N.; Epron, F.; de Freitas Silva, T.; Guimarães Maciel, C.; Mansur Assaf, J.; do Carmo Rangel, M. Catal. Today 2014, 228, $40-50$.

[31] Moretti, E.; Storaro, L.; Talon, A.; Riello, P.; Infantes Molina, A.; Rodríguez-Castellón, E. Appl. Catal. B Env. 2015, 168-169, 385-395. 
[32] Gong, L.; Huang, Z.; Luo, L.; Zhang, N. Reac. Kinet. Mech. Cat. 2014, 111, 489-504.

[33] Manzoli, R.; Di Monte, F.; Boccuzzi, S.; Coluccia; Kašpar, J. Appl. Catal. B Env. 2005, $61,192-205$.

[34] Kaspar, J.; Fornasiero, P.; Graziani, M. Catal. Today 1999, 50, 285-298.

[35] Bueno-López, A.; Krishna, K.; Makkee, M.; Moulijn, J. J. Catal. 2005, 230, 237-248.

[36] Aneggi, E.; de Leitenburg, C.; Dolcetti, G.; Trovarelli, A. Catal. Today 2006, 114, 40-47.

[37] Strobel, R.; Krumeich, F.; Pratsinis, S.E.; Baiker, A. J. Catal. 2006, 243, 229-238. 
1
2
3
4
5
6
7
8
9

10

11

12

13

14

15

16

17

18

19

20

21

22

23

24

25

26

27

28

29

30

31

32

33

34

35

36

37

38

39

40

41

42

43

44

45

46

47

48

49

50

51

52

53

54

55

56

57

58

59

60

\section{Table of Contents Graphic}



